y: ABC. - ISSN 1451-1053. - God. 18, br. 1 (2018), str. 8-15.

616-07:621.3

COBISS.SR-ID 262369548

\title{
The Importance Of Telemedicine In Medical Emergencies
}

\section{Sladjana R Vujacic}

Institute for emergency medical services Podgorica

\section{Summary:}

Modern health systems aim to increase the quality of health care. Considering all the advantages that modern technologies can offer as well as the importance of adequate diagnostics and emergency medical therapy, the need for using those advantages in the treatment of emergency patients is only logical.

Telemedicine represents the provision of health services through the use of information and telecommunication technologies regardless of geographical location of the medical team, patient or medical equipment.

Active implementation of telemedicine can contribute to reducing of health care costs, to improving cooperation between different levels of health protection, to providing quick consultations in emergency medical conditions as well as to education of health workers.

In order to provide quality emergency medical care good cooperation with general hospitals and clinical centers is necessary. This cooperation would be possible through creation of virtual teams, groups of physicians who work in different time, geographic and organizational areas with the goal of setting up a quicker and more precise diagnosis.

Health systems tend to economize, standardize services and deliver best results. The formation of virtual teams, supported by the opportunities provided by information technologies of today, will contribute to better organization of work in health department, to significant improvement of quality, speed and accuracy in setting diagnosis and consequently to faster decisionmaking on further therapeutic action with less health care costs.

Keywords: telemedicine, emergency medicine, tele-emergency, information technology . 


\section{Introduction:}

Modern medicine and its tendency for more efficient resolution of different medical issues brought the need for exploitation of all the possibilities that information technologies can offer. Simplified, this implies the use of computers. Thanks to the global computer network called the Internet, it is possible to connect the desired number of computers and enable smooth communication at any time. Modern medicine now has the ability to easily collect and exchange data, to quickly and efficiently solve health problems, as well as to access easily all new medical discoveries [1].

Through the strategic document "Health for All in the Third Millennium" of the World Health Organization, the Strategy for the Development of Information and Communication Technologies in Health and the Action Plan of the European Commission, strategic and operational goals and activities were set in Europe to effectively address the challenges facing health systems. All health services have been set up to enable easy communication between patients and health facilities, interaction of health workers and better education.

Health services are not limited anymore to the obligatory presence of a patient and a physician in the same place, because it is now possible to provide health service regardless of their geographical distance.

One of the major challenges of medical informatics is to provide adequate interoperability between different information systems at different levels. Interoperability can be divided into several levels: physical, software and semantic.

- Physical level - defines how to physically connect institutions

- Software level -defines mechanisms for data exchange between institutions

- Semantic level - defines mechanisms that allow data to be further exchanged [2].

\section{History of emergency medicine}

The application of computer technologies is widespread through all segments of modern life. We can say that it has significantly facilitated all kinds of modern life activities. The possibility of incredibly quick and efficient communication that computer technologies provide brought also the rapid development in various medical fields. Emergency medicine is a branch of medicine in which the positive effects of communication technologies can significantly improve the work that has been done so far.
Physicians who are dealing with emergencies are struggling to rescue human lives every minute. Fast and effective communication among colleagues, among institutions, fast and high-quality diagnostics and therefore quality decision making on further treatment, can all lead to the increase in number of rescued lives.

The modern era in which society often faces disasters with mass destruction and emergency situations, requires inclusion of information and communication technologies in everyday work.

The need for helping others, who need help, is something we are faced with daily.

Therefore, it may be safe to say that the emergency medical care exists as long as human civilization.

The earliest records of some kind of organized medical facility for providing emergency medical assistance mention "Drowning aid station" established in 1762 in Hamburg and "Voluntary Rescue Society" in Vienna. The literature also mentions the "Chinkiang Society for the Saving of Life" founded in 1708 .

There are records of some forms of emergency medical assistance during $15^{\text {th }}$ century in war-torn areas in Spain, which were provided in special tents and improvised hospitals. During wars in $18^{\text {th }}$ century, French surgeons Jean-Dominique Larrey and Pierre-François Percy were organizers and providers of emergency medical assistance. They introduced the use of special resources and organized transport for wounded and sick people. The first recorded use of artificial respiration "mouth-to-mouth" for massive injuries was in 1732 during rescue of miners after an accident in the coal mine in Dublin.

Dr. Hawes and Dr. Cogan in 1773 promoted a new technique to resuscitate patients. In 1774, the "The Royal Human Society" was founded, with primary goal to provide aid to drowned people.

However, the official founder and father of Emergency Aid is Henry Dunant. In 1859, after the Battle of Solferino, he started the first organized medical help for the wounded, and then after a few years The Red Cross was founded. The first Civil Emergency Medical Service in the United States was established in Cincinnati in 1865.

In 1870 during the siege of Paris, the first air transportation of patients occurred, by means of an observation balloon. Transport by helicopter was first performed in 1951 during the Korean War.

In 1956, physicians Peter Safar and James Elam developed a method of ventilation "mouth to mouth" in the Baltimore City Hospital. Peter Safar is consid- 
ered to be the father of cardiopulmonary resuscitation.

The first defibrillator was invented in 1959 by William B. Kouwenhofen, who worked at the Johns Hopkins University's School of Engineering. In 1966, Dr. Pantridge developed a program of prehospital emergency care for patients in Belfast. Hospital St. Vincent in New York in 1968 organized the first mobile cardiological team.

The first educational program for doctors of medicine specialized in the field of emergency medicine was established in 1972 at the University of Cincinnati [3].

Telemedicine represents using of telecommunication technologies with the purpose of providing health protection and exchange of information from afar. It implies the transmission of information such as: radiographic images, computerized tomography images, magnetic resonance images, ultrasound, endoscopic procedures, transfer of patient conversations, consultations among doctors, education etc.

Telemedicine has been present for more than 30 years, but its progress has been more significant over the past 5 to 10 years. During the ' 60 s, the National Agency for Aeronautics and Space Administration NASA played an important role in the development of telemedicine. In those years the astronauts sent reports to the agency on earth. In the same period, NASA and the American Health Service began to provide health care for people living in Indian reservations in Arizona, which included X-ray images and electrocardiograms transferred using cellular and satellite-based communication.

The microwave connection between the Boston airport and the general hospital Massachusetts was established in 1967.

During the 70's, teledermatology has been developed to treat skin diseases on space flights.

In the same period, School of Medicine in Miami provided telemedicine for prisoners.

In 1986, the Mayo Clinic began to conduct a twoway satellite program between the Mayo Camp in Rochester, Minnesota and Arizona in order to assist colleague physicians who are at remote geographic locations $[4,5]$.

Telemedicine represents the transfer of medical data from one location to another using information and communication technologies. In this way, it becomes possible to transfer medical data regardless of the current location of the medical team and patient; therefore it is possible to provide quality medical services without restriction at any time, in any place.
Telemedicine applications include telediagnosis, teleconsultation, telemonitoring, telecare, teleconsilium.

Telemedicine programs can not be successfully formed and developed without the successful cooperation of doctors and engineers. Before organizing the telemedicine program, detailed education of engineers involved in the development of programs and technologies is required.

Adequate cooperation between doctors and engineers provides conditions for creating programs that will be easy to use and give best results. In this way, the conditions will be created for the information technologies to be best used at a given moment [6].

Telemedicine in emergency situations

Providing of emergency medical care is significantly more complicated nowadays, despite new diagnostic and therapeutic forms, because of all the challenges doctors are facing every day. At the end of 20th and at the beginning of 21 st century, we are witnessing new developments on global stage in which, along with other professionals, healthcare workers in the emergency medicine sector play an e $\mathrm{xtremely}$ i m portant role. Emergency situations, disasters, both natural and human-induced, are new challenges posed in everyday work.

Climate changes that lead to natural disasters, terrorism, wars, they all threaten the population in the economic, social and cultural sphere, but most importantly they threaten people's lives. The origin and consequences of these events are something we cannot foresee, so we cannot create adequate methods of preventing them. Although disasters make such destructive consequences on whole population, they still have not been recognized as a significant topic for training and education about dealing with them. However, in recent years, the awareness of healthcare workers and others about the importance of preparing and acting in emergencies has increased. Today in some countries there are subspecializations in the field of disasters and emergency public health.

In any emergency situation, quality and fast communication between the services is necessary. New technologies enable quick communication between the teams of emergency assistance, regional hospitals and hospital centers, police officers, firefighters and all those involved in protection and rescue.

Telemedicine is conceived as a fairly simple concept. It involves collection of data by multiple sensors and transmission to other centers for further 
processing, consultation, analysis, diagnostics and therapeutic recommendations. What may be an obstacle to a relatively simple, imaginary process are technical possibilities or impossibilities. However, the development of information technology has led to reducing all these difficulties to a minimum.

One of the greatest benefits of telemedicine in providing emergency medical care is that the examination of a patient can be done anywhere, under any conditions whether they are regular, ideal, unfavorable or extraordinary, while communication with the greatest medical experts who can provide all necessary instructions for the team on the ground or prepare for the arrival of a life-threatened patient is open and available the whole time, even during transport [7].

\section{Standardization}

The standardization in the field of medical informatics deals with the worldwide ISO (International Organization for Standardization) and IEC (International Electrotechnical Commission). At European level, competent institutions are CEN (European Committee for Standardization), CENELEC (European Committee for Standardization in the Field of Electrical Engineering) and ETSI (European Institute for Standards in the Field of Telecommunications).

Technical committees for standardization of medical informations are responsible for standardization in the field of data exchange, construction of medical tables, photos and terminology, transmission and protection of information in healthcare systems.

Particular attention is dedicated to the protection of data from possible misuse, protection of personal data and protection of access to certain documents.

At the end of the 1980s, the standardization of message exchange between different information systems was introduced for the first time. The goal of this message standardization and integration of the subsystem is to achieve optimum financing as a whole. In the field of information exchange in healthcare sector, many people, both healthcare beneficiaries and donors, manufacturers, professional institutions, the Ministry of Health and others, participate in the process of introducing standards.

Standards can be divided into three groups:

1. Terminological standards

2. Communication standards

3. Safety standards

HL7 (Health Level seven)

HL7 are communication standards that enable electronic data exchange within the health care sys- tem. The first organization for dealing with these standards was formed in 1987 in the US. The field of its action was defined at the founding session, and the first version of the new standard was established. The second version of the standard was adopted in 1989, and in 1990, the implementation of version 2.1 of the HL7 communication standard was introduced. In March 1997, version 2.3, expanding its scope, now includes standards for data exchange that relate to:

1. Patient-related administrative tasks,

2. Clinical patient information,

3. Patient care information,

4. Provision of medical services,

5. Management of medical services,

6. Distribution of patients and resources,

7. Report on unwanted effects,

8. Report on Clinical Experiments, Immunization

The HL7 Group cooperates with other standardization institutions working on International and European news through the work of technical committees. CEN / TC 251 and ISO / TC215 are in charge of medical informatics [8,9].

ISO (International Organization for Standardization) represents the world federation of national standardization organizations. It is formed in order to enable easy coordination and unification of standards.

One of the most important responsibilities of a modern society is to ensure the availability of quality health services and technologies.

So far, ISO has published over 1000 standards related to health systems. ISO Technical Committee (TC 215) deals with health informatics and recognizes it as an important way of improving health care, optimizing use of health resources and generating knowledge in health sector. The goal of TC 215 is the compatibility and consistency of health information and data with effective exchange and the possibility of updating [10].

The European Committee for Standards CEN (Comité Europeen de Normalization, Brussels) adopted a package of standards for the health information system that was named CEN TC251. On that occasion, a standard architecture for health information systems was set up so that they could be integrated and able to exchange information. The standards that apply to this are ENV12967 - HISA Healthcare Information System Architecture. The eEurope Action Plan is an information technology program through which the European Commission defined the development of health information systems in the European Union. This plan also stipulates that the program should be introduced to the 
institutions of the Government, health institutions, educational institutions, social institutions and other necessary institutions [11].

\section{Organization of emergency services}

The organization of institutions dealing with emergency medical care differs in different countries. Emergency service in Montenegro includes fieldwork in ambulances, work in outpatient conditions and work in the call center. Emergency medical assistance begins with an urgent call to a doctor in the call center. Upon receiving the call, the available medical team gets engaged to perform the medical intervention as fast as possible and in the best possible way. Providing medical services today is complicated by many other factors: complicated medical conditions, patients with several comorbidities, inefficient existing therapy, new forms of diseases emerging, extraordinary circumstances in terms of illness and injury of a large number of people, natural disasters and terrorist attacks $[12,13]$.

Many studies have suggested that the implementation of telemedicine has positive effects except for clinical and economic outcomes. Nevertheless, implementation of telemedicine and quality information system improve patient's outcome, they shorten the time for making and implementing decisions, which ultimately gives positive economic effects [14].

\section{Virtual team}

Cooperation among health workers is a necessary part of everyday work. Without good mutual cooperation, best results cannot be expected. In the process of diagnosis and treatment of each patient, it is precious to have a colleague's opinion. This way you know that you will get the best final outcome. Emergency medicine is a true example of the importance of teamwork.

One of the exceptional advantages of using information and communication technologies is the possibility of forming virtual teams. Creating a virtual team with the ability to quickly transfer all necessary information provides the best final outcome for patients.

Geographically Dispersed Team - GDT is a group of individuals working in different time, space and regulatory environments. With the use of these technologies it is possible to overcome all existing obstacles (15).

Creating a virtual team in providing emergency mediation helps, for example, during the patient's transport to a regional hospital or clinic. For instance, the physician cardiologist receives all the necessary information about the patient being trans- ported, he receives anamnestic and clinical facts during transport, the values of his blood pressure, frequency, pulse state, saturation, heart and lung findings, ECG findings and other, and in this way prior to the arrival of the patient he can make a decision on further treatment. It is not necessary to explain further all positive effects of this arrangement. In the same way radiologists can be consulted to interpret images wherever they are, as well as other experts.

By creating a virtual team, problem present in a large number of countries in the world, lack of physicians, can be overcome and an adequate level of health care quality can be maintained.

In addition to the use in emergency medical situations, the creation of a virtual team and telemedicine gives the opportunity to treat many chronic illnesses. For example, arterial hypertension is one of the most important public health problems of modern times, as well as one of the most common reasons for visiting a doctor. The modern way of life, often sedentary, associated with irregular meals, reduced physical activity, etc. and with other risk factors can lead to an increase in arterial pressure values in the category of employed persons.

This increase in incidence of arterial hypertension in the working-age population, associated with frequent occurrence of complications, points to the fact that arterial hypertension along with its complications becomes an increasingly frequent reason for absenteeism and premature retirement, which represents a significant social-economic problem and once again points to the exceptional importance of prevention and adequate treatment. Telemedicine can be extremely helpful in treatment of this disease, because by forming virtual teams and by using all the benefits that telemedicine provides, it would be possible to adequately treat these patients wherever they are [16].

\section{Teleemergency}

Teleemergency means equipping all mobile facilities, ambulances, helicopters, and public transport vehicles (buses, trains, planes, boats), places of public gatherings (schools, faculties, sports facilities, restaurants, hotels) with a portable telemedicine set (Portable Telemedicine Kit - PTK).

\section{The PTK should have:}

-a digital stethoscope for audio recordings of heart and lungs findings, electrocardiogram, highresolution digital camera for recording external pictures and videos (capturing eye, nose, ear, throat, and skin findings)

-lap top computer for collecting, storing, sending 
information to telemedicine centers with all necessary communication modules, and a backup powering system for tough conditions [17].

Telemedicine is an opportunity to effectively manage the distance and obstacles that a geographic distance carries with you. The implementation of telemedicine in the daily work of doctors for a long time could not be adequately performed due to insufficient scientific evidence on the effectiveness of telemedicine [18].

\section{Conclusion}

The implementation of the telemedicine project in emergency medical care would bring a number of benefits and it would improve the urgent treatment of patients. Emergency medicine is one of the areas of medicine that requires quick and adequate response; therefore telemedicine can make significant progress in this area.

However, in order for this project to be efficiently applied, it is necessary to fulfill a number of prerequisites. Telemedicine requires the existence of suitable diagnostic and therapeutic equipment which will allow its implementation. All health workers must be educated and informed prior to the implementation of telemedicine.

The use of telemedicine can also minimize the influences of weather and geographical barriers. This way, the health system, and the quality of health protection can be improved, provision of emergency assistance more efficient, the possibility for education of all health workers would be open, and ultimately health care costs would be reduced. Taking into consideration the benefits of telemedicine in the future, how it would enable better and more efficient emergency medical help and the final outcome of patients' health which directly depends on this efficiency, the significance of implementing telemedicine in this field becomes clear. 


\section{Literature:}

1. Milović B. Information and communication technology in healthcare and in the development of e-health. Yu info. 2011. Available from: http://yuinfo.artkey.rs/ zbornici/2011/html/pdf/061.pdf

2. World Health Organization. Framework and Standards for Country Health nformation Systems $-2^{\text {nd }}$ ed. 2007. Available from: http://apps.who.int/iris/ bitstream/10665/43872/1/9789241595940_eng.pdf

3. Arnold J. International Emergency Medicine and the Recent Development of Emergency Medicine Worldwide. Annals of Emergency Medicine. 1999; 33 (1): 97-103.

4. Kayser K, Kayser G, Radziszowski D, Oehmann A. New developments in digital pathology: from telepathology to virtual pathology laboratory. Studies in health technology and informatics, 2004, 105: 61-69.

5. Kayser K, Kayser G. Basic aspects of and recent developments in telepathology in Europe, with specific emphasis on quality assurance. Analytical and quantitative cytology and histology, 1999; 21(4), 319-328.

6. Milosavljević G, Čurović T. It is easier with teledentistry. Acta stomatologica Naissi. 2012; 28 (66), 1205-1218. Available from: http://scindeks-clanci.ceon.rs/ data/pdf/0352- 5252/2012/0352-52521266205M.pdf

7. Nola I.A, Jelinić Doko J. Zdravstveni menadžment katastrofa. Sigurnost. 2012; 54 (2), 165-172. Available from: http://hrcak.srce.hr/83865

8. Kern J. Standardization in Health and Medical Informatics. In: Lazakidou AA (ed). Handbook of Research on Informatics in Health Care and Biomedicine. HersheyLondon-Melbourne-Singapore: Idea Group Inc. 2006.

9. Vidović T. Standardizacija u medicinskoj informatici. Glasnik BAS, Institutut za standardizaciju Bosne i Hercegovine. 2009. Available from: http:// www.bas.gov.ba/images/upload/glasnik/ glasnik_1_2_09cl3.pdf

10. ISO i zdravstvo. Institut za standardizaciju Srbije. 2016. Available from: http://www.iss.rs/images/upload/ PUBLIKACIJE/iso_i_zdravstvo.pdf

11. CEN - CENELEC response to the European Commssion's Public Consultation on Transformation of Health and Care in the Digital Single Market. European Committee for Standardization. 2017. Available from: https://www.cencenelec.eu/news/policy_opinions/ policyopinions/reply_ehealth.pdf

12. Schuster M, Pints M, Fiege M. Duration of mission time in prehospital emergency medicine: effects of emergency severity and physicians level of education. Emergency Medicine Journal. 2010; 27(5), 398-403. Available from: http://emj.bmj.com/content/27/5/398.full

13. Czaplik M, Bergrath S, Rossaint R, Thelen S, Brodziak T, Valentin B, Brokmann JC. Employment of telemedicine in emergency medicine. Methods of information in medicine. 2014; 53(2), 99-107.
14. Leong J. R, Sirio C. A., Rotondi A. J. eICU program favorably affects clinical and economic outcomes. 2005. Available from: https://ccforum.biomedcentral.com/ articles/10.1186/cc3814

15. Anđelić S, Kostić L. Virtuelni timovi u telemedicini. Jahorina: Infoteh. 2012;709-714. Available from: http:// www.infoteh.rs.ba/zbornik/2012/radovi/RSS-4/RSS-48.pdf

16. Vujačić S. Rasprostranjenost arterijske hipertenzije među korisnicama usluga. Zavoda za hitnu medicinsku pomoć u Podgorici. Timočki medicinski glasnik. 2017;42 (1), 18-25.

17. Gagnon M. P, Légaré F, Fortin J. P., Lamothe L, Labrecque M., Duplantie J. An integrated strategy of knowledge application for optimal e-health implementation: a multi-method study protocol. BMC Medical Informatics and Decision Making. 2008; 8(1), 17.

18. Wootton R. Telemedicine. BMJ. 2001; 323(7312), 557 -560. Available from: http://www.bmj.com/ content/323/7312/557.1

Primljen - Received: $\quad 01.02 .2018$. Ispravljen - Corrected $\quad 01.03 .2018$. Prihvaćen - Accepted: 26.03.2018. 


\section{VAŽNOST TELEMEDICINE U MEDICINSKI HITNIM STANJIMA}

Sladjana R Vujačić

Institut za Hitnu medicinsku pomoć Podgorica

\section{Sažetak:}

Svi moderni zdravstveni sistemi imaju za cilj poboljšanje kvaliteta zdravstvene zaštite. Ako se uzme u obzir kakve sve prednosti nude moderne tehnologije, kao i to koliki je značaj adekvatne dijagnostike i izbora terapije, logično je da se javila potreba za korišćenjem upravo tih prednosti u tretmanu urgentnih stanja.

Telemedicina predstavlja novi način pruženja zdravstvenih usluga kroz upotrebu informacionih i telekomunikacionih tehnologija, a bez obzira na to gde se fizički nalazi medicinski tim u odnosu na pacijenta.

Aktivna implementacija telemedicine može da doprinese smanjenju troškova u zdravstvu, poboljšanju saradnje različitih nivoa zdravstvene zaštite, realizaciji brzih konsultacija u urgentnim situacijama, kao i edukaciji zdravstvenih radnika.

Dobra saradnja između opštih bolnica i kliničkih centara je neophodan uslov za realizaciju kvalitetne zdravstvene zaštite. Formiranjem virtuelnih timova, tačnije grupa lekara koji rade geografski i organizaciono u različitim oblastima, a sa ciljem bržeg i preciznijeg postavljanja dijagnoze, ova saradnja bi bila olakšana.

Zdravstveni sistemi imaju za cilj takođe i smanjenje troškova, standardizaciju usluga i ostvarivanje najboljih rezultata. Formiranje pomenutih virtuelnih timova podržanih informacionim tehnologijama, doprineće boljoj organizaciji rada u zdravstvenom sistemu, značajnom poboljšanju kvaliteta, brzine i preciznosti u dijagnostikovanju, a naposletku i bržem izboru daljeg terapijskog delovanja uz smanjenje troškova. tehnologije .
Ključne reči: telemedicina, urgentna medicina, informacione 